\title{
Institutional Environment, Ownership Structure and Accounting Earning Quality
}

\author{
He Jinri \\ Business School of Hunan University \\ Hunan University \\ Changsha, China
}

\author{
Liu Xinran \\ Business School of Hunan University \\ Hunan University \\ Changsha, China,13808457063 \\ lxr_123@126.com
}

\begin{abstract}
This paper empirically examines the relationships between the institutional environment, ownership structure and accounting earning qulity based on the data Chinese listed companies in 2007-2009. It finds that the better the insitutional environment in the rigion, the higher the quality of accounting earning of listed companies; ownership concentration has a significant negative correlation with the quality of accounting earning information; the government-controlled listed companies has a higher quality of accounting earning information. And institutional environment plays as a complementary role in the governance effects of ownership structure, good institutional environment can reduce the ownership concentration's negative effect on the quality of accounting earning information; the institutional environment's effect on the quality of accounting earning information exists significant difference between government-controlled companies and non-governmentcontrolled companies.
\end{abstract}

Keywords-Accounting earning quality; Institutional environment; Ownership structure; Governance efficiency

\section{INTRODUCTION}

China's securities market has made great achievements during the last 20 years. Securities market not only broaden the financing channels for enterprises, but also has gradually become an important driving force of China's economic development. However, the development of securities markets can not be achieved without authentic and reliable accounting earning information. While our government continue to regulate the disclosure of accounting information, but the quality of accounting information of listed companies are generally not high. The distortion problem is serious and earnings manipulation is too excessive. Some companies even exist serious accounting fraud behavior. Public Company Accounting fraud cases brought tremendous trauma to the Chinese stock market, which greatly hurt the the confidence of majority investor, and damage the function of the securities markets.

From the surface, the quality of accounting information of listed companies is due to the lack of accounting professional ethics and the failure of the external audit function. However, the problem of accounting earning quality is the result of poor corporate governance. Information asymmetry caused by the separation of ownership of the modern enterprise, as well as principal-agent conflict is the deep-seated reasons of the accounting earning quality problems, and due to the prevalence of major shareholders, the main principal-agent relationship is the principal-agent between minority shareholders and major shareholders. How to reasonable arrangements the ownership structure to reduce the principal-agent relationship is the key to improve governance efficiency.

In the study of corporate behavior and corporate value, an increasing number of scholars believe that the institutional environment has an impact on the companys' corporate actions. In this paper, we first consider the impact of ownership structure on the accounting earning quality, and then explore if the institutional environment will impact the ownership structure's influence on the accounting earning quality, as well as if the relationship between the insitutional envirnment and the accounting earning qulity will be different in different companies.

The rest of this article is organized as follows: Section II is a literature review and propose hypotheses; Section III is the design of research methods; The fourth quarter is the empirical results and analysis; Finally, the conclusions of this study.

\section{THE LITERATURE REVIEW AND THE TESTABLE HYPOTHESES}

\section{A. Ownership structure and accounting earning quality}

La Porta et al (1998) finds that ownership concentration is negatively correlated with the quality of financial reporting. Joseph PH Fan, TJ Wong (2002) found that there is negative correlation between corporate ownership concentration and enterprise earning quality. The controlling shareholder will disclose information according to their own interests, which makes the quality of the report low. Huang Qian (2006) uses the the cross-section of the Jones model to analysis of the the the association between the ownership concentration and earnings management based on the data of list companies in Shanghai Exchange in 2002-2003. The reault shows that the proportion of big shareholders' shares and earnings management is positively correlated. Wang Huacheng and Huang Xinjian (2007) use the ST listed companies as the study samples to analyse the relationship between the the Earnings Management and the corporate governance structure, the results show that the degree of concentration and Earnings Management has a positive correlation. 
Chinese listed companies are highly concentrated and most listed companies are controlled by large shareholders. Fan and Wang (2002) find that a high concentration of ownership will increase the agency conflicts between large shareholders and minority shareholders. The higher the degree of ownership concentration, the greater the controlling shareholder to distort the accounting earning information for self-serving purpose. So hypotheses is proposed:

H1: With other things being equal, the higher the degree of ownership concentration, the higher the extent of earnings management of listed companies and the lower the quality of accounting information.

Liu Liguo and Du Ying (2003) find it does not exist a significant relationship between the proportion of state shares and financial reporting fraud, and when the company's largest shareholder is Treasury, the company is more likely to occur the financial Corrupt. Li Chang Qing and Guan Lianyun (2004) insist that the stake of the state-owned shares, the shareholding proportion of legal person shares and tradable shares of the relationship between the stake and earnings management size was not significant. Du Xingqiang, Wen Riguang (2007) find that state-controlled listed companies have a higher quality of accounting information than non-state-controlled listed companies. Gao Lei, Zhang Jie (2009) find that the state holding company has a poor internal governance, manage earnings frequently.

Since China is still in a transitional economy period, the reform of state-owned enterprises are slow, and most enterprises are still controlled by the government. If the ultimate controller is the Government, the listed companies will bear the government's social functions so that the company's activities deviate from the value maximization goal. So hypotheses is proposed:

H2: With other things being equal, the governmentcontrolled listed companies have a large extent of earnings management and low quality of accounting information.

\section{B. The institutional environment's effect on corporate governance}

La Porta et al (1998, 1999a) find the stronger investor protection and the efficiency of law enforcement in a region or a country, the enterprises there will have a more dispersed ownership structure. Haw (2004) finds that the earnings management caused by the ownership and control separation is significant suppressed in countries with a high level of legal protection. Wang, Wong and Xia (2005) find that lower external audit quality of listed companies with state-owned background weakened the quality of financial accounting information disclosure of listed companies. However, in the region with less government intervention in the economy and better credit market or legal environment development, there is no difference in employing high-quality auditors between stateowned enterprises and non state-owned enterprises. Gao Lei and Zhang Jie (2009) find that the higher the degree of legalization in the region, the more listed companies subject to the supervision of the constraints, and the more stringent listed companies regulate their own behavior. The listed company which under a high degree of government intervention lacking of incentive to improve internal corporate governance. Jiang Yingbing, Yan Ting (2012)find that the higher the level of regional market-oriented, the better legal protection and the less government intervention; the higher the efficiency of listed companies on the implementation of the Accounting Standards in that region.

Building on all the studies above, we think that with better institutional environment, the enterprise will have hagher accounting earning quality, so we propose the following hypotheses:

H3:With other things being equal, the listed companies in the areas with higher degree of market-oriented development higher level of legal system and less government intervention, the accounnting earning qulity will be higher.

H4: With other things being equal, the better the external institutional environment of listed companies, the smaller the ownership concentration's negative effect on the accounting earning quality.

H5: With other things being equal, as opposed to government-controlled listed companies, non-governmentcontrolled listed companies' accounting earning quality is more vulnerable to the impact of the institutional environment.

\section{DATA AND RESEARCH DESIGN}

\section{A. Data sources}

Our data come from various sources. First, we selected the companies listed in Shanghai and Shenzheng Exchange in 2007-2009. Then we removed ST listed companies, financial listed companies, companies missing the ultimate holding characteristic information and other companies of the missing data. The final total number of samples is 2720 , with 905 companies in 2007, 898 companies in 2008, 917 companies in 2009. The ultimate holding characteristic information of the data used in this article come from Wind database, and other data are from the GTA database.

\section{B. The definition of variables}

1) The dependent variable. Sloan (1996) point out that the low level of earnings management means that the manipulation of the accounting earning is small, and it is a manifestation of high quality accounting information. Burgstahler(2006), Paul K (2011) also use the extent of earnings management as indicators to measure the quality of accounting information. Drawing on the above-mentioned literature, this paper uses the reverse of the earnings management to measure the quality of accounting earning information. We propose to use the modified Jones model to calculate the maneuverability accrued profits(DA) and use its absolute value | DA | as a measure of the extent of earnings management.

2) The independent variables. For the institutional environment variable, we use the marketization index in various regions of China in 2009 released by Fan Gang (2010) with reference to Li Sihai's (2010) approach. And we select three indexs: the overall index of marketization process, the 
index of the relationship between government and market, as well as the regional legal index of the institutional environment and the legal environment. For the mesurement of ownership structure varialbe, we select the proportion of the top five shareholders as the mesurement of ownership concentration, and differentiate government-controlled enterprises from nongovernmental enterprises according to the characteristic of ultimate controller.

3) The control variables. Based on the research results at home and abroad, we select firm size (Size), financial leverage (Lev), company growth (Growth), Company net return on assets (Roe) and the proportion of independent directors (Sd) as control variables. All variable definitions and computation methods of variables are shown in Table 1.

TABLE I. DEFINITION OF VARIABLES

\begin{tabular}{|c|c|c|c|}
\hline $\begin{array}{l}\text { Variable } \\
\text { group }\end{array}$ & Variable name & $\mathbf{A b b}$ & Variable computation \\
\hline $\begin{array}{l}\text { Dependent } \\
\text { variable }\end{array}$ & $\begin{array}{c}\text { Extent of } \\
\text { earning } \\
\text { management }\end{array}$ & $|\mathrm{DA}|$ & $\begin{array}{c}\text { Absolute value of the } \\
\text { maneuverability accrued } \\
\text { profits calculated by Jones } \\
\text { model } \\
\end{array}$ \\
\hline \multirow[t]{5}{*}{$\begin{array}{l}\text { Independent } \\
\text { variables }\end{array}$} & \multirow{2}{*}{$\begin{array}{l}\text { Ownership } \\
\text { structure } \\
\text { varialbe } \\
\text { (Own) }\end{array}$} & Top5 & $\begin{array}{c}\text { Proportion of the top five } \\
\text { shareholders }\end{array}$ \\
\hline & & Gov & $\begin{array}{l}\text { Dummy variable, "1" } \\
\text { means government- } \\
\text { controlled. }\end{array}$ \\
\hline & \multirow{3}{*}{$\begin{array}{l}\text { Institutional } \\
\text { environment } \\
\text { variables } \\
\text { (Index) }\end{array}$} & Mar & $\begin{array}{c}\text { Overall index of } \\
\text { marketization process from } \\
\text { Fan Gang(2010) }\end{array}$ \\
\hline & & Law & $\begin{array}{l}\text { The regional index of legal } \\
\text { environment from Fan } \\
\text { Gang(2010) }\end{array}$ \\
\hline & & Inv & $\begin{array}{l}\text { The index of government } \\
\text { Intervention from Fan } \\
\text { Gang(2010) }\end{array}$ \\
\hline \multirow[t]{7}{*}{$\begin{array}{c}\text { Control } \\
\text { variables }\end{array}$} & Firm size & Size & $\begin{array}{c}\text { The natural logarithm of } \\
\text { company's total assets at } \\
\text { the end of the year }\end{array}$ \\
\hline & $\begin{array}{l}\text { Financial } \\
\text { leverage }\end{array}$ & Lev & $\begin{array}{c}\text { The company's asset- } \\
\text { liability ratio }\end{array}$ \\
\hline & $\begin{array}{l}\text { Company } \\
\text { growth }\end{array}$ & Grow & $\begin{array}{l}\text { (Main income this year - } \\
\text { main income last year) / he } \\
\text { main business income last } \\
\text { year }\end{array}$ \\
\hline & $\begin{array}{l}\text { Company net } \\
\text { return on assets }\end{array}$ & Roe & Net profit / net assets \\
\hline & $\begin{array}{l}\text { Proportion of } \\
\text { inde- } \\
\text {-pendent } \\
\text { directors } \\
\end{array}$ & $\mathrm{Sd}$ & $\begin{array}{l}\text { The proportion of } \\
\text { independent directors in all } \\
\text { the directors }\end{array}$ \\
\hline & Year & Year & Dummy variable \\
\hline & Industry & Indu & Dummy variable \\
\hline
\end{tabular}

\section{Research design}

The To test the H1 and H2, we establish the equation (1), (2) for the sample test.

$|\mathrm{DA}|=\mathrm{a}_{0}+\mathrm{b}_{1}$ Top $5+\mathrm{b}_{2}$ Size $+\mathrm{b}_{3}$ Lev $+\mathrm{b}_{4}$ Grow $+\mathrm{b}_{5}$ Roe $+\mathrm{b}_{6} \mathrm{Sd}+\sum$

$\mathrm{b}_{\mathrm{i}}$ Year $+\sum \mathrm{b}_{\mathrm{j}}$ Indu

$|\mathrm{DA}|=\mathrm{a}_{0}+\mathrm{b}_{1}$ Gov $+\mathrm{b}_{2}$ Size $+\mathrm{b}_{3}$ Lev $+\mathrm{b}_{4}$ Grow $+\mathrm{b}_{5}$ Roe $+\mathrm{b}_{6} \mathrm{Sd}+\sum$ $\mathrm{b}_{\mathrm{i}}$ Year $+\sum \mathrm{b}_{\mathrm{j}}$ Indu
For H3 and H4, we establish equation (3), (4) for inspection; for H5, we will differentiate government-controlled enterprises from non-governmental enterprises and use equation (3) to test both kinds of enterprises.

$|\mathrm{DA}|=\mathrm{a}_{0}+\mathrm{b}_{1}$ Index $+\mathrm{b}_{2}$ Size $+\mathrm{b}_{3}$ Lev $+\mathrm{b}_{4}$ Grow $+\mathrm{b}_{5}$ Roe $+\mathrm{b}_{6} \mathrm{Sd}+\sum$ $\mathrm{b}_{\mathrm{i}}$ Year $+\sum \mathrm{b}_{\mathrm{j}}$ Indu

$|\mathrm{DA}|=\mathrm{a}_{0}+\mathrm{b}_{1}$ Top5 $+\mathrm{b}_{2}$ Top $5 *$ Index $+\mathrm{b}_{3}$ Size $+\mathrm{b}_{4}$ Lev $+\mathrm{b}_{5}$ Grow ${ }^{+}$ $\mathrm{b}_{6}$ Roe $+\mathrm{b}_{7} \mathrm{Sd}+\sum \mathrm{b}_{\mathrm{i}}$ Year $+\sum \mathrm{b}_{\mathrm{j}}$ Indu

In equation (3) and equation (4), "Index" is the intitutional environment variable, "Index * Top5" is a regulation variable. In the regression process, the variable "Index" and "Top5" are centralized, that means, all values of these two variables should minus the mean of the variable respectively.equations are an exception to the prescribed specifications of this template. You will need to determine whether or not your equation should be typed using either the Times New Roman or the Symbol font (please no other font). To create multileveled equations, it may be necessary to treat the equation as a graphic and insert it into the text after your paper is styled.

\section{THE EMPIRICAL RESULTS AND ANALYSIS}

\section{A. Descriptive statistics}

Table 2 shows the the average, median, maximum, minimum and standard deviation statistics of each variable. From the table, we find that the maximum value of earnings management (manoeuvrable as the absolute value of accruals) is 7.0326, and the minimum is 0.00001 , indicating that the extent of earnings management of listed companies have a great difference. The mean and median values of the shares concentration are 0.4901 and 0.4946 , and the maximum value reaches to 0.9602 . That means the list companies in China have a very high level of shares concentration. The average of dummy variable which describe ultimate holding characteristics is 0.6912 . It tells us that more than half of the listed companies in China are under the control of government. And for the institutional environment index, we find that here are big gap between the maximum and the minimum of the marketization process, legalization process, government intervention, indicating that economic development of different regions are imbalance and institutional environment difference is large in different regions.

TABLE II. DESCRIPTIVE STATISTICS OF MAIN VARIABLES

\begin{tabular}{|c|c|c|c|c|c|}
\hline $\begin{array}{c}\text { Variable } \\
\text { name }\end{array}$ & Ave & Med & Min & Max & $\begin{array}{c}\text { Standard } \\
\text { deviation }\end{array}$ \\
\hline$|\mathrm{DA}|$ & 0.1196 & 0.0851 & 0.0001 & 7.0326 & 0.2023 \\
\hline Top5 & 0.4901 & 0.4946 & 0.1037 & 0.9602 & 0.1533 \\
\hline Gov & 0.6912 & 1 & 0 & 1 & 0.4621 \\
\hline Mar & 8.5245 & 8.76 & 0.38 & 11.8 & 1.9784 \\
\hline Law & 9.9683 & 7.42 & 0.18 & 19.89 & 5.0626 \\
\hline Inv & 8.8087 & 9.28 & -4.66 & 10.42 & 1.5868 \\
\hline Size & 21.802 & 21.709 & 16.508 & 27.487 & 1.1416 \\
\hline Lev & 0.5226 & 0.5246 & 0.0183 & 12.238 & 0.2969 \\
\hline Growth & 0.3131 & 0.1164 & -0.9844 & 58.356 & 1.9563 \\
\hline Roe & 0.0751 & 0.0739 & -6.7743 & 4.7308 & 0.3215 \\
\hline Sd & 0.3594 & 0.3333 & 0.0909 & 0.6 & 0.0495 \\
\hline
\end{tabular}




\section{B. Regression result and analysis}

Table 3 is the regression result of the ownership structure and accounting earning quality for all sample companies. Model 1 is used for prove hypotheses 1 . In this model, The ownership concentration and earnings management have a positive relationship significantly in the $1 \%$ level, which in line with our expectation, indicating the higher the concentration in the listed companies, the larger the earnings management and the lower the accounting earning quality. The model 2 is based on the hypotheses 2 . We find from the regression results that the results are contrary to the our expectation, and significantly in the $1 \%$ level. It means government-controlled listed companies have less earnings management and higher accounting earning quality than non-government-controlled listed companies. The conclusion is the same as Du Xingjiang, Wen Riguang's (2007) conclusion. It may due to the reason that government-controlled listed companies do not necessarily regard profit as the only goal. As they also bear some social responsibility, the extent of earnings management is lower; On the other hand, the state is strengthening companies' internal control construction recent years, which started from the government-controlled listed companies. The effectiveness of internal controls makes it more difficult for the governmentcontrolled listed companies to manipulate profits, so they have high quality of accounting earnings.

TABLE III. THE REGRESSION BETWEEN OWNERSHIP STRUCTURE AND ACCOUNTING EARNING QUALITY

\begin{tabular}{|c|c|c|c|}
\hline Variables & Expected & Model 1 & Model 2 \\
\hline (constant) & & 0.105 & 0.038 \\
\hline Top5 & + & $0.127^{* * *}$ & $-0.025^{* * *}$ \\
\hline Gov & + & & 0.001 \\
\hline Size & - & $-0.006^{* *}$ & $0.110^{* * *}$ \\
\hline Lev & + & $0.109^{* * *}$ & $0.027^{* * *}$ \\
\hline Growth & + & $0.027^{* * *}$ & 0.001 \\
\hline Roe & - & -0.001 & 0.050 \\
\hline Sd & - & 0.056 & Control \\
\hline Year & & Control & Control \\
\hline Indu & & Control & 2720 \\
\hline Sample & & 2720 & 0.128 \\
\hline Size & & & $21.992^{* * *}$ \\
\hline Adj-R2 & & 0.133 & \\
\hline Value F & & $22.927^{* * *}$ & \\
\hline
\end{tabular}

* Indicates significantly in the $10 \%$ level; ** indicates a significant level of $5 \%$; *** expressed significantly in the $1 \%$ level。

Table 4 and Table 5 are the regression results of model 3 and model 4 for the full sample. Model 3 is for testing hypotheses 3. By replacing the "Index" with the variable Mar, Law and Inv respectively, we get the results of model 3.1, 3.2 and 3.3 below. We find that the extent of earnings management is significant negatively correlated to the variable Mar and Inv in the level of $5 \%$ and $1 \%$ respectively, which indicating that the higher in the process of marketization and the less government intervention in the region, the lower level of earnings management and the higher accounting earning quality; we also find that the correlation between legal level index and the extent of earnings management is not significant. This may due to the poor overall legal environment of China. The legal efforts to protect the investors is not enough, so it can not improve the accounting earning quality of listed companies. Model 4 is the result of hypotheses 4 . We find that in the regression the coefficient of "Mar*Top5", “Law*Top5” and "Inv*Top5" are significant in the $1 \%, 10 \%$ and $1 \%$ level respectively, indicating that a better institutional environment, such as a high degree of marketization, high level of legal protection and less government interventio, can inhibit the controlling shareholder's earnings management behavior and reduce the ownership concentration's negative effect on the accounting earning quality. In the control variables, we find that financial leverage and the extent of earning management has a significant positive correlation, indicating that the higher the ratio of company's financial liabilities, the lower the accounting earning quality. The company's growth and the extent of earning management are positively correlated, indicating that the company in a rapid growth period is more likely to engage in earnings management behavior. The correlation between company size, return on net assets and earnings management was not significant. The coefficient between proportion of independent directors and extent of earnings management is positive, which is different from our expectation, but it does not pass the test of significance in the $10 \%$ level, indicating that the independent directors of listed companies in China does not really play a governance role in improving the quality of accounting earning information.

TABLE IV. THE REGRESSION OF INSTITUTIONAL ENVIRONMENT AND ACCOUTING EARNING QUALITY

\begin{tabular}{|c|c|c|c|c|}
\hline \multirow{2}{*}{ Variable } & \multirow{2}{*}{ Expected } & \multicolumn{3}{|c|}{ Model 3 } \\
\cline { 3 - 5 } & & Model 3.1 & Model 3.2 & Model 3.3 \\
\hline (constant) & & 0.083 & 0.066 & $0.132^{*}$ \\
\hline Mar & - & $-0.004^{* *}$ & & \\
\hline Law & - & & 0.000 & \\
\hline Inv & - & & & $-0.012^{* * *}$ \\
\hline Top5 & + & & & 0.001 \\
\hline Size & - & 0.000 & 0.000 & $0.108^{* * *}$ \\
\hline Lev & + & $0.109^{* * *}$ & $0.110^{* * *}$ & $0.027^{* * *}$ \\
\hline Growth & + & $0.027^{* * *}$ & $0.027^{* * *}$ & 0.001 \\
\hline Roe & - & 0.002 & 0.002 & 0.049 \\
\hline Sd & - & 0.050 & 0.055 & 0.001 Control \\
\hline Year & & Control & Control & Control \\
\hline Indu & & Control & Control & Control \\
\hline Sample Size & & 2720 & 2720 & 2720 \\
\hline Adj-R2 & & 0.126 & 0.125 & 0.133 \\
\hline Value F & & $21.675^{* * *}$ & $21.432^{* * *}$ & $22.933^{* * *}$ \\
\hline
\end{tabular}

TABLE V. THE REGRESSION BETWEEN OWNERSHIP STRUCTURE AND ACCOUNTING EARNING QUALITY

\begin{tabular}{|c|c|c|c|c|}
\hline \multirow{2}{*}{ Variable } & \multirow{2}{*}{ Expected } & \multicolumn{3}{|c|}{ Model 4 } \\
\cline { 3 - 5 } & & Model 4.1 & Model 4.2 & Model 4.3 \\
\hline (constant) & & $0.169^{* *}$ & $0.163^{* *}$ & $0.200^{* * *}$ \\
\hline Top5 & + & $0.130^{* * *}$ & $0.128^{* * *}$ & $0.135^{* * *}$ \\
\hline Mar *Top5 & - & $-0.55^{* * *}$ & & \\
\hline Law *Top5 & - & & $-0.008^{*}$ & \\
\hline Inv *Top5 & - & & & $-0.171^{* * *}$ \\
\hline Size & - & $-0.006^{*}$ & -0.006 & $-0.008^{* *}$ \\
\hline Lev & + & $0.110^{* * *}$ & $0.109^{* * *}$ & $0.111^{* * *}$ \\
\hline Growth & + & $0.027^{* * *}$ & $0.027^{* * *}$ & $0.026^{* * *}$ \\
\hline Roe & - & -0.002 & -0.002 & 0.000 \\
\hline Sd & - & 0.074 & 0.065 & 0.088 \\
\hline Year & & Control & Control & Control \\
\hline Indu & & Control & Control & Control \\
\hline Sample Size & & 2720 & 2720 & 2720 \\
\hline Adj-R2 & & 0.139 & 0.134 & 0.166 \\
\hline Value F & & $22.922^{* * *}$ & $21.951^{* * *}$ & $28.148^{* * *}$ \\
\hline
\end{tabular}


In order to test the hypothesis 5, we differentiate government-controlled enterprises from non-governmental enterprises according to the characteristic of ultimate controller and test with the regression model 3 . The results are showed in Table 6. By Table 6 we found that, in the governmentcontrolled listed companies, the institutional environment have no significant influence on the accounting earning quality; but in the non-government-controlled listed companies, good institutional environment can reduce the earning management, which means that good institutional environment can improve the accounting earning quality in non-government-controlled companies. The reason of this may be that under the control and protection of government, the government-controlled listed companies is more difficult to be affected by the institutional environment. The regulation and law of government are more difficult to constrain government itself.

TABLE VI. THE REGRESSION BETWEEN INSTITUTIONAL ENVIRONMENT AND ACCOUNTING EARNING QUALITY IN THE LIST COMPANIES WITH DIFFERENT ULTIMATE CONTROLLING SHAREHOLDER

\begin{tabular}{|c|c|c|c|c|c|c|}
\hline \multirow[t]{2}{*}{$\begin{array}{c}\text { Variab } \\
\text { le }\end{array}$} & \multicolumn{3}{|c|}{$\begin{array}{l}\text { Government-controlled } \\
\text { comapnies }\end{array}$} & \multicolumn{3}{|c|}{$\begin{array}{l}\text { Non-government-controlled } \\
\text { companies }\end{array}$} \\
\hline & $\begin{array}{c}\text { Model } \\
3.1\end{array}$ & $\begin{array}{c}\text { Model } \\
3.2\end{array}$ & $\begin{array}{c}\text { Model } \\
3.3\end{array}$ & $\begin{array}{c}\text { Model } \\
3.1\end{array}$ & $\begin{array}{l}\text { Model } \\
3.2\end{array}$ & $\begin{array}{c}\text { Model } \\
3.3\end{array}$ \\
\hline constant & -0.086 & -0.081 & -0.085 & 0.105 & 0.090 & 0.122 \\
\hline Mar & 0.001 & & & $0.013^{* * * *}$ & & \\
\hline Law & & 0.001 & & & -0.003 & \\
\hline Inv & & & 0.001 & & & $0.022^{* * * *}$ \\
\hline Size & $0.009^{*}$ & $0.009^{*}$ & $0.009^{*}$ & 0.000 & -0.004 & 0.001 \\
\hline Lev & 0.018 & 0.014 & 0.017 & $0.141^{\text {* }}$ & $0.140^{* * n}$ & $0.141^{* * 4}$ \\
\hline Growth & $0.015^{* * *}$ & $0.015^{\text {*** }}$ & $0.015^{* * *}$ & $0.067^{* * * *}$ & $0.067^{* * *}$ & $0.066^{* * *}$ \\
\hline Roe & 0.014 & 0.014 & 0.014 & -0.017 & -0.016 & -0.20 \\
\hline Sd & -0.40 & -0.039 & -0.40 & 0.224 & 0.236 & 0.265 \\
\hline Year & Control & Control & Control & Control & Control & Control \\
\hline Indu & Control & Control & Control & Control & Control & Control \\
\hline Sample & 1880 & 1880 & 1880 & 840 & 840 & 840 \\
\hline Adj-R2 & 0.103 & 0.103 & 0.103 & 0.210 & 0.205 & 0.223 \\
\hline Value F & $12.345^{*}$ & $12.407^{* *}$ & $12.325^{*}$ & $13.415^{*}$ & $13.017^{*}$ & $14.399^{*}$ \\
\hline
\end{tabular}

\section{THE CONCLUSION OF THE RESEARCH}

This paper carried out empirical research on the relationship between the institutional environment, ownership structure and accounting earning quality based on 2007-2009 Chinese Ashare listed companies. The study found that: (1) Ownership concentration and accounting earning quality has a significant negative correlation. (2) Relative to non-government-controlled listed companies, government-controlled listed companies has a higher quality of accounting earning quality. (3) The higher the process of marketization of the listed companies and the lower the degree of government intervention, the higher the quality of accounting information of listed companies. (4) The region which a listed company locate in has a higher marketization process, a higher level of legal protection and a lower degree of government intervention, the ownership concentration's negative impact on accounting earning quality will be lower. (5) As opposed to government-controlled listed companies, the quality of accounting earnings in nongovernment-controlled listed companies are more susceptible to the positive impact of the institutional environment.
Therefore, when we concern about the quality of accounting earnings of listed companies, on the one hand, we should pay attention to the impact of ownership structure and internal governance; on the other hand, we should also consider the more important factor which hide behind in the ownership structure and internal governance --- the institutional environment. Only if we accelerate the speed of the marketization process, strengthen the legal protection of investors, reduce the extent of government intervention can create a better institutional environment for public companies.If good Institutional environment and internal governance structure combined with each other, influence each other, the listed companies will have higher governance efficiency, better quality of accounting earning information and greater value of the company.

\section{REFERENCES}

[1] Burgstahler David C, Luzi Hail, Christian Leuz. "The Importance of Reporting Incentives: Earning Management in European Private and Public Firms”, Accounting Review, 81, pp. 983-1016, 2006.

[2] Du Xingqiang, Wen Riguang. “Corporate Governance and Quality of Accounting Information:An Empirical Research”, Journal of Finance and Economics, 1, pp. 122-133, 2007.

[3] Durnev A, E.H. Kim. "To Steal or not Steal: Firm Attributes, Legal Environment, Valuation”, Journal of Finance, 60(3), pp. 1461-1493, 2005.

[4] Fan Gang, Wang Xiaolu, Zhu Hengpeng. "Neri Index of Marketization of China’s Provinces 2009 Report”, Beijing: Press of Economic Science, 2010.

[5] Fan,J.P.H. and T.J.Wang. “Corporate Ownership and Control”, Journal of Law and Economics, 26(6), pp. 401-425, 2002.

[6] Gao Lei, Zhang Jie. "Corporate Governance, Earnings Management and Firm Growth”, Economic Theory and Business Management, 12, pp. 53-59, 2009

[7] Gao Lei, Zhang Jie. "On the Corporate Governance, Fund Appropriation and Earning Manipulation”, Journal of Finance and Economics, 5, pp. 121-140,2009.

[8] Huang Qian. "An Empirical Research on the Relationship between Major Shareholders, Managers' Ownership and Earnings Management”, Statistics and Decision, 18, pp.109-111, 2006.

[9] Huang Xinjian, Wu Jiang. "On Firms orporate Governance and Earnings Management-Base on the Validates of Chinese ST Listed Companies”, Ecological Economy, 1, pp.78-82, 2007.

[10] Jiang Yingbing, Yan Ting. "Institutional Environment' s Impact on Execution of Accounting Standards”, Accounting Research, 4, pp.69-78, (2012)

[11] La Porta R., F. Lopez-de-Silanes, A. Shleifer, R. Vishny. "Law and Finance”, Journal of Political Economy, 106(6), pp.1113-1155, (1998)

[12] Lei Gao, Gerhard Kling, "The impact of corporate governance and external audit on compliance to mandatory disclosure requirements in China”, Journal of International Accounting, Auditing and Taxation, 12, pp.17-31, 2012.

[13] Li Wei'an, Corporate Governance Evaluation and Index Research[M].Beijing: Press of Higher Education, 2005.

[14] Liu Liguo, Du Ying. "An Empirical Research on the Relationship between Corporate Governance and the Quality of Accounting Information”, Accounting Research, 2, pp. 28-36, 2003.

[15] Paul K, Chaney, Mara Faccio, David Parsley. "The Quality of Accounting information in politically connected firms". Journal of Accounting and Economics, 51, pp. 58-76, 2011.

[16] Sloan,R. "Do Stock Price Reflect Information in Accruals and Cash Flow about Future Earnings?”, Accounting Review, 71(3), pp.281-308, 1996.

[17] Wang Yongmei. "EmpiricaI Study on Index of Voluntary Corporate Disclosure”, Securities Market Herald, 9, pp. 45-49, 2003. 